\title{
Activity-independent intracellular signaling contributes to rate variability among neurons in the globus pallidus
}

\author{
Christopher A Deister ${ }^{*}$, Ramana Dodla, David Barraza, Charles J Wilson
}

From Nineteenth Annual Computational Neuroscience Meeting: CNS*2010

San Antonio, TX, USA. 24-30 July 2010

Synchrony among neurons is seen throughout the mammalian CNS, in particular within networks of GABAergic neurons. The globus pallidus (GP) consists of GABAergic neurons that project to neurons throughout the basal ganglia in addition to each other via local axon collaterals. The GP does not display synchronous rhythms and there are no clear correlations between neurons in healthy mammals. In contrast, strong correlations among GP neurons emerge in Parkinson's disease patients and MPTP treated primates. Why GP neurons show no correlations in healthy animals is not known. GP neurons are autonomous pacemakers and are thought to discharge at a constant frequency. Theoretical work shows that the degree of synchrony in interconnected networks depends on the amount of heterogeneity in firing rate.

We have observed in cell-attached recordings of GP neurons, in slices, that their firing rates are not stationary, but instead visit a range of rates over a period of one hour in a non-stereotypical fashion. The fluctuations in rate are stable for periods of minutes, can vary as much as $30 \mathrm{~Hz}$, and appear to be unaffected by blocking synaptic inputs. HCN channels are a critical component of the GP neuron's pacemaking mechanism, and their availability is positively correlated with the firing rate of GP neurons. Paired recordings revealed that these fluctuations in rate were neuron-independent. We hypothesized that these slow non-stereotypical fluctuations in firing rate could be attributed to regulation of $\mathrm{HCN}$ channels by cAMP. cAMP alters $\mathrm{HCN}$ availability by shifting the channel's activation curve to depolarized potentials. Consistent with this, up-regulation of cAMP levels by bath

\footnotetext{
* Correspondence: chris.deister@utsa.edu

University of Texas - San Antonio/Neurosciences Institute
}

application of $50 \mu \mathrm{M}$ Forskolin increased the firing rate of GP neurons from $12.7 \pm 1.3$ to $20.5 \pm 1.5 \mathrm{~Hz}$. After the Forskolin induced increase in firing rate stabilized, there was a marked decrease in the amount of variability in interspike intervals (ISIs) observed over a one hour period of recording in the cell-attached configuration. In control conditions the average coefficient of variation of ISIs $(\mathrm{CV})$, measured over one hour, was $0.43 \pm 0.22$ and was $0.09 \pm 0.02$ after exposure to Forskolin. Thus, fluctuations in cAMP can create heterogeneity in firing rate among GP neurons by altering the availability of the voltage-gated ion channels necessary to drive pacemaking. By this mechanism, activity independent intracellular signaling could potentially contribute to the absence of synchrony in the GP.

Published: 20 July 2010
doi:10.1186/1471-2202-11-S1-P152

Cite this article as: Deister et al: Activity-independent intracellular signaling contributes to rate variability among neurons in the globus pallidus. BMC Neuroscience 2010 11(Suppl 1):P152.

Submit your next manuscript to BioMed Central and take full advantage of:

- Convenient online submission

- Thorough peer review

- No space constraints or color figure charges

- Immediate publication on acceptance

- Inclusion in PubMed, CAS, Scopus and Google Scholar

- Research which is freely available for redistribution

Submit your manuscript at www.biomedcentral.com/submit
C Biomed Central 